\title{
Traumatic open globe injury-epidemiology, risk factors and visual outcome at the University Hospital Aachen
}

\author{
Yassamin Djalali-Talab (D) B Babac Mazinani $(\mathbb{D}) \cdot$ Yassin Djalali-Talab $(\mathbb{D}$
}

Received: 23 May 2020 / Accepted: 12 December 2020 / Published online: 6 January 2021

(C) The Author(s) 2021

\begin{abstract}
Summary
Background Ocular trauma is still a major cause leading to enucleation. This study aims to analyze the visual outcome, epidemiology and risk factors of open globe injury (OGI) at the University Hospital Aachen, Germany.

Material and methods A retrospective analysis of patient records involving traumatic OGI treated surgically between 2005 and 2015 was conducted. Age, gender, cause of accident, ocular trauma score, best corrected visual acuity (BCVA) at presentation and after treatment as well as location of injury were evaluated.

Results Of 2272 eyes with trauma, 102 patients with OGI were identified, of which $65 \%$ were male and $35 \%$ were female. Women were significantly older than men $(p<0.001)$. The most common cause of injury was domestic syncopal episodes $(47 \%)$. Work-related injuries occurred exclusively in men in $8.8 \%$. A total of $16 \%$ had no light perception (NLP) at presentation, $69 \%$ of which improved post intervention to hand movement or better. Endophthalmitis was observed in $4 \%$ of all cases. Enucleation was needed mostly due to rupture. Location of OGI, pseudophakia and initial BCVA are risk factors for poor final BCVA. Patients' BCVA did not improve further after three surgeries. Conclusion Traumatic OGI still poses a challenge in terms of treatment planning and prognostic outcome. A rise in elderly patients with multimorbidity represents a secondary obstacle to treatment. Patients with initial NLP can be treated with moderate success. Nevertheless, risk factors and ocular trauma score are unable to provide definitive therapy decisions. OGI
\end{abstract}

\footnotetext{
Y. Djalali-Talab · B. Mazinani, MD · Y. Djalali-Talab, MD, FEBO $(\bowtie)$

Department of Ophthalmology, RWTH Aachen University, Pauwelsstr. 30, 52074 Aachen, Germany

ydjalali@ukaachen.de
}

should be assessed case by case, taking risk factors for OGI into account. Treating physicians should consider the ethical and economic reasons with regard to whether a high number of surgeries with possible comorbidities is justified.

Keywords Perforation · Eye injury · Ocular Trauma Score $\cdot$ No light perception $\cdot$ Endophthalmitis

Traumabedingte bulbuseröffnende Verletzung Epidemiologie, Risikofaktoren und Visusentwicklung am Universitätsklinikum Aachen

\section{Zusammenfassung}

Hintergrund Die bulbuseröffnende Verletzung ist weiterhin einer der häufigsten Gründe für Enukleationen. Diese 10-Jahres-Studie gibt einen Überblick über Visusentwicklung, Epidemiologie und Risikofaktoren am Universitätsklinikum Aachen.

Material und Methoden In einer retrospektiven Untersuchung wurden Patienten, die im Zeitraum von 2005 bis 2015 eine durch Trauma verursachte bulbuseröffnende Verletzung oder Ruptur mit operativer Behandlung erlitten hatten, hinsichtlich Alter, Geschlecht, Unfallhergang, Ocular Trauma Score, Visus („,best corrected visual acuity“ [BCVA] vor und nach chirurgischer Intervention) sowie Perforationsstelle erfasst.

Resultate Es fanden sich 2272 Patienten mit Augenverletzung, von denen 102 bulbuseröffnend waren. Der Großteil (65\%) war männlich. Frauen waren signifikant älter als Männer $(p<0,001)$. Der häufigste Grund waren häusliche Unfälle, insbesondere vasovagale Synkopen und Stürze $(47 \%)$. Arbeitsunfälle betrafen nur Männer (8,8\%). $16 \%$ aller Patienten stellten sich mit Nulla-lux-Visus vor, der sich in $69 \%$ der Fälle durch Intervention mindestens auf Finger- 
zählen verbesserte. Eine Endophthalmitis trat in $4 \%$ aller Fälle auf. Eine Enukleation war hauptsächlich bei Rupturen erforderlich. Die Lokalisation der Bulbuseröffnung, eine Pseudophakie und der initiale BCVA bei Vorstellung sind maßgebende Risikofaktoren für einen schlechten finalen Visus. Der BCVA konnte nach drei Eingriffen nicht weiter verbessert werden. Schlussfolgerung Traumatische bulbuseröffnende Verletzungen bleiben eine Herausforderung, sowohl in der Behandlungsplanung als auch bezüglich der Prognose. Die demografische Verschiebung hin zu älteren Patienten mit häufigeren Komorbiditäten stellt eine zusätzliche Hürde in der Therapie dar. Patienten, die sich bereits mit Nulla-lux-Visus vorstellen, können langfristig mit mäßigen Erfolgsaussichten behandelt werden. Bulbuseröffnende Verletzungen sollten unter Berücksichtigung entsprechender Risikofaktoren von Fall zu Fall beurteilt werden. In die Überlegung, ob zahlreiche chirurgische Interventionen bei möglichen Komorbitäten gerechtfertigt sind, sollten ethische und ökonomische Aspekte einfließen.

Schlüsselwörter Perforation · Augenverletzung · Ocular Trauma Score $\cdot$ Nulla lux $\cdot$ Endophthalmitis

\section{Introduction}

Ocular trauma is still a major cause leading to $37-60 \%$ of all enucleations, next to glaucoma, endophthalmitis and keratitis [1, 2]. It significantly impacts patients' quality of life, career and self-perception. Ocular trauma has a broad variety of sequelae ranging from full visual acuity and minor aesthetic impacts up to primary or secondary enucleation [3]. Cataract surgery, myopia, higher age and female gender have previously been identified as ocular risk factors [4]. Eye injuries are commonly classified with the Birmingham Eye Trauma Terminology System (BETTS) [5] and the Ocular Trauma Score (OTS) [6] to evaluate the prognostic outcome [7].

Causes and epidemiology for open globe injuries (OGI) differ according to geographic region and population. Whereas in Asia work-related injuries account for $43-74 \%$ of all OGI [8-10], the numbers in Europe and the US are $23-34 \%[10,11]$ and $13 \%$ [3], respectively. Risk factors for poor outcome include age, endophthalmitis, vitreoretinal trauma, low OTS, no light perception (NLP), latency between injury and surgery and severity of trauma [12-16].

The authors aimed to evaluate the demographics, causes and visual outcome of OGI in their patient cohort.

\section{Materials and methods}

The medical records of 2272 patients with eye trauma between 2005 and 2015 were reviewed. Subjects with contusion as well as patients receiving only conservative therapy were excluded. The medical charts of 102 traumatic OGI patients that underwent surgical treatment at the University Hospital Aachen, Germany, were retrospectively assessed. Age, gender, accident cause, initial visual acuity and complications were evaluated. Final visual acuity and missing long-term data were collected by surveying referring ophthalmologists in 2016. Best corrected visual acuity (BCVA) values were converted from decimal to logMAR and special importance ascribed to low vision values $[17,18]$. OTS was derived from initial BCVA, rupture, endophthalmitis, perforating injury, retinal detachment (RD) and afferent pupillary deficit. Of those 102 patients, the OTS could be calculated in 88 patients. In 14, OTS was not derivable due to missing clinical data. The location of OGI was categorized as corneal injury (grade I), limbus parallel scleral injury (grade II) or radial scleral injury without or with eye muscle involvement (grade III and IV). Enucleation was not a standard procedure at presentation and was only considered after unsuccessful therapy, chronic pain or for cosmetic reasons.

In agreement with local ethics rules for this type of study, formal consent was not required but patient approval was obtained before surveying referring ophthalmologists.

Data is presented as mean \pm standard deviation (SD) unless stated otherwise. This research is presented according to the Strengthening the Reporting of Observational studies in Epidemiology (STROBE) guidelines [19].

The incidence rate was calculated using PowerAnalyzer (trinovis GmbH, Hannover, Germany) with data provided by the German Federal Statistical Office (www.destatis.de). Population and patient numbers were used to calculate the annual incidence rate. Statistical analysis was done with IBM SPSS Statistics for Windows, version 24.0.0.0 (IBM Corp., Armonk, NY, USA). The statistical test was chosen depending on the type of variables and data distribution. Graphs were plotted with GraphPad Prism for Windows, version 6.01 (GraphPad Software, San Diego, CA, USA) or Microsoft Excel for Windows, version 2020 (Microsoft Corp., Redmond, WA, USA).

\section{Results}

\section{Patient demographics}

In 2016, the authors' tertiary care center was within reach of $1,303,617$ people. A total of 102 patients were identified with traumatic OGI over a 10-year period, leading to an incidence rate of 0.8 cases $/ 100,000$ people per year. Follow-up was $26.1 \pm 29.0$ months.

Gender distribution is presented in Fig. 1, with $65 \%$ being male and $35 \%$ female (Table 1). Men were significantly younger than women $(46.7 \pm 20.9$ vs. $79.6 \pm 16.3$ years; $t$-test, $p=0.001$ ).

Most patients were injured due to accidental falling or syncopal episodes (47\%). Common injuries were on 


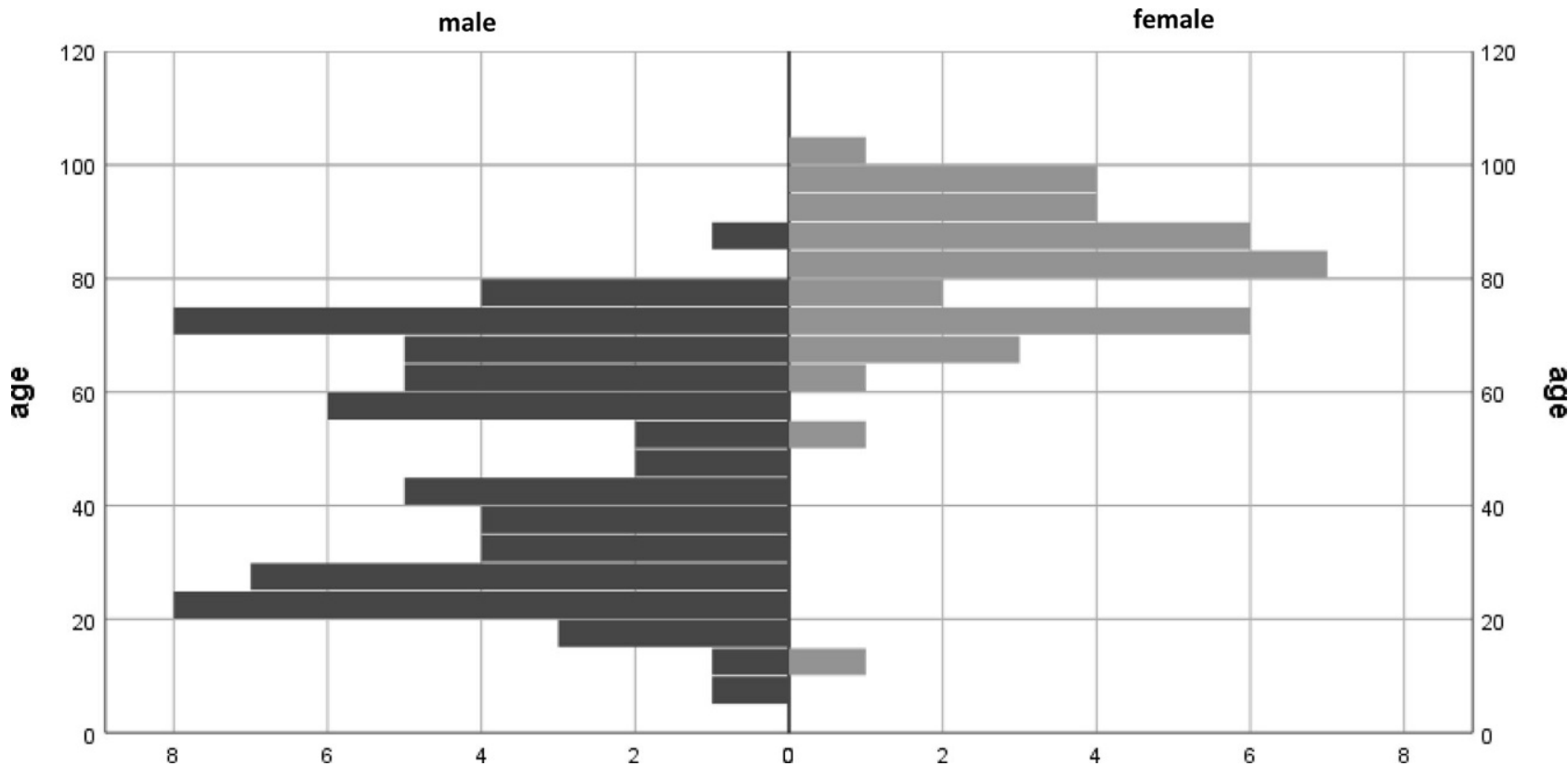

Fig. 1 Gender-based numbers of patients categorized by age

\begin{tabular}{|c|c|}
\hline Variables & Frequency ( $n$ ) \\
\hline \multicolumn{2}{|l|}{ Sex } \\
\hline Male & 66 \\
\hline Female & 36 \\
\hline \multicolumn{2}{|l|}{ Age } \\
\hline$\leq 50$ & 36 \\
\hline$\geq 51$ & 66 \\
\hline \multicolumn{2}{|l|}{ Type of injury } \\
\hline Rupture (all) & 81 \\
\hline Rupture (blunt force) & 40 \\
\hline Perforating/penetrating injury w/o IOFB & 8 \\
\hline Penetrating injury with IOFB & 13 \\
\hline \multicolumn{2}{|l|}{ Location of injury } \\
\hline Grade I & 30 \\
\hline Grade II & 28 \\
\hline Grade III & 18 \\
\hline Grade IV & 18 \\
\hline \multicolumn{2}{|l|}{ Lens status at presentation } \\
\hline Pseudophakic & 26 \\
\hline Other & 76 \\
\hline \multicolumn{2}{|l|}{ Type of IOFB } \\
\hline Metal & 7 \\
\hline Wood & 1 \\
\hline Glass & 3 \\
\hline Other & 2 \\
\hline IOFB intraocular foreign body & \\
\hline
\end{tabular}

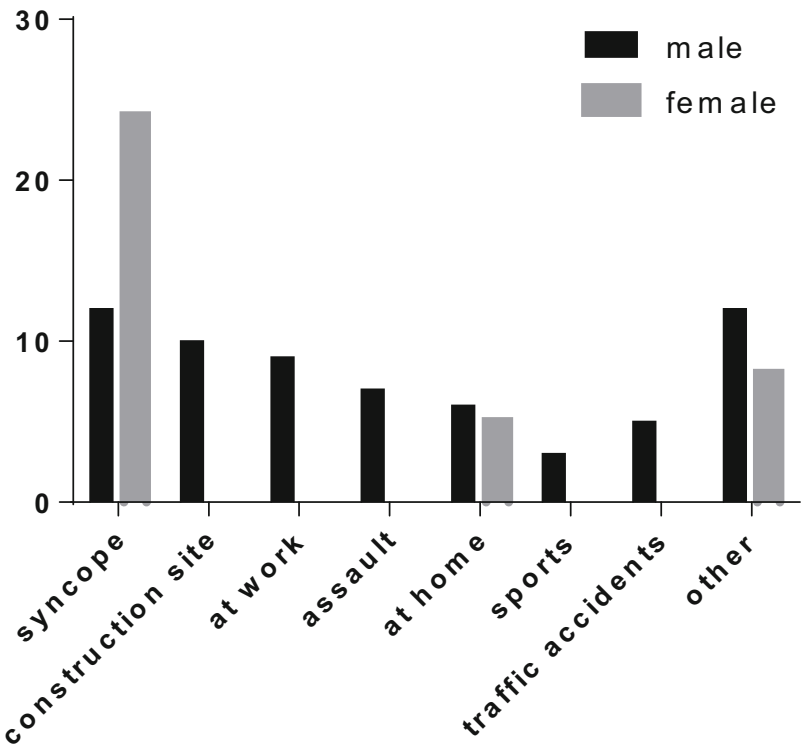

Fig. 2 Distribution of accident causes in percent

a construction site or at work (22\%; Fig. 2). Other individual causes were hooks, tension belts, fireworks, bursting firewood or iatrogenic injection. The most common perforating or penetrating items were metallic (16\%) like nail and tool splinters, wooden $(6 \%)$ like wood shavings and glass (14\%) like broken bottles and shattered eyeglasses. Rupture injury was mostly due to blunt force $(41 \%)$. Wood, plastic or glass caused similar poor visual outcome compared to injuries by blunt force or rupture ( $t$-test, $p=0.07$ ) (see Table 2). 
Table 2 Statistical analysis of visual outcome

\begin{tabular}{|c|c|c|c|}
\hline & At presentation & Last follow-up & $p$-Value \\
\hline \multicolumn{4}{|l|}{ All patients } \\
\hline $\begin{array}{l}\mathrm{BCVA} \pm \mathrm{SD}(\log \mathrm{MAR}) \\
n\end{array}$ & $\begin{array}{l}2.16 \pm 0.86 \\
101\end{array}$ & $\begin{array}{l}1.53 \pm 1.1 \\
102\end{array}$ & $0.000^{*}$ \\
\hline \multicolumn{4}{|l|}{ Treated with silicone oil } \\
\hline \multirow[t]{2}{*}{$\begin{array}{l}\mathrm{BCVA} \pm \mathrm{SD}(\log \mathrm{MAR}) \\
n\end{array}$} & $\begin{array}{l}2.59 \pm 0.48 \\
42\end{array}$ & $\begin{array}{l}2.09 \pm 0.85 \\
42\end{array}$ & $0.000^{*}$ \\
\hline & Pseudophakic at presentation & All other & $p$-Value \\
\hline \multicolumn{4}{|l|}{ At presentation } \\
\hline $\begin{array}{l}\mathrm{BCVA} \pm \mathrm{SD}(\log \mathrm{MAR}) \\
n\end{array}$ & $\begin{array}{l}2.37 \pm 0.75 \\
26\end{array}$ & $\begin{array}{l}2.09 \pm 0.89 \\
68\end{array}$ & $0.16 \mathrm{~ns}$ \\
\hline \multicolumn{4}{|l|}{ Last follow-up } \\
\hline \multirow[t]{2}{*}{$\begin{array}{l}\mathrm{BCVA} \pm \mathrm{SD}(\log \mathrm{MAR}) \\
n\end{array}$} & $\begin{array}{l}1.96 \pm 0.89 \\
26\end{array}$ & $\begin{array}{l}1.41 \pm 1.13 \\
72\end{array}$ & $0.03^{*}$ \\
\hline & $\begin{array}{l}\text { Penetrating injury by wood, plastic, } \\
\text { glass }\end{array}$ & $\begin{array}{l}\text { Rupture by blunt } \\
\text { force }\end{array}$ & $p$-Value \\
\hline \multicolumn{4}{|l|}{ Last follow-up } \\
\hline \multirow[t]{2}{*}{$\begin{array}{l}\text { Mean } \mathrm{BCVA} \pm \mathrm{SD} \text { (logMAR) } \\
n\end{array}$} & $\begin{array}{l}1.31 \pm 1.15 \\
52\end{array}$ & $\begin{array}{l}1.80 \pm 0.97 \\
40\end{array}$ & $0.07 \mathrm{~ns}$ \\
\hline & Penetrating injury by metal & All other & p-Value \\
\hline \multicolumn{4}{|l|}{ Last follow-up } \\
\hline \multirow[t]{2}{*}{$\begin{array}{l}\emptyset \mathrm{BCVA} \pm \mathrm{SD} \text { (logMAR) } \\
n\end{array}$} & $\begin{array}{l}0.55 \pm 0.98 \\
16\end{array}$ & $\begin{array}{l}1.74 \pm 1.01 \\
76\end{array}$ & $0.000^{*}$ \\
\hline & Tissue prolapse at presentation & No prolapse & p-Value \\
\hline \multicolumn{4}{|l|}{ Last follow-up } \\
\hline $\begin{array}{l}\mathrm{BCVA} \pm \mathrm{SD}(\log \mathrm{MAR}) \\
n\end{array}$ & $\begin{array}{l}1.54 \pm 0.81 \\
76\end{array}$ & $\begin{array}{l}1.26 \pm 1.10 \\
12\end{array}$ & $0.29 \mathrm{~ns}$ \\
\hline
\end{tabular}

Table 3 Correlation of Ocular Trauma Score (OTS) to final best-corrected visual acuity (BCVA) and OTS to total number of surgeries

\begin{tabular}{|c|c|c|c|}
\hline & 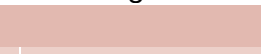 & \multirow{2}{*}{$\begin{array}{l}\text { Final BCVA } \\
-0.686^{*}\end{array}$} & \multirow{2}{*}{$\begin{array}{l}\text { No. of surgeries } \\
-0.370^{\star}\end{array}$} \\
\hline \multirow{3}{*}{$\begin{array}{l}\text { OTS } \\
\text { score }\end{array}$} & Correlation coefficient & & \\
\hline & & $0.000^{\star \star}$ & $0.000^{\star \star}$ \\
\hline & $\begin{array}{l}\text { Correlation coefficient } \\
p \text {-Value } \\
n\end{array}$ & 88 & 86 \\
\hline
\end{tabular}

\section{Location of open globe injury}

The present data show a correlation between higher grade (grade III and IV) injuries to worse final visual acuity, a higher number of surgeries and retinal detachment (RD) (Spearman correlation: final BCVA: $p<0.0001$; number of surgeries: $p<0.0001$; RD: $p<0.0001$ ) (see Table 2). In all, $26.5 \%$ of patients had pseudophakia at presentation with a mean age of $78.54 \pm 10.2$ years. Phaco incision site was a predilection site for rupture in only $10 \%$.

\section{Tissue prolapse}

Prolapse of vitreous occurred in $25 \%$, of iris in $32 \%$ and lens expulsion in $4.5 \%$. Undefined prolapse was found in $25 \%$. Of all patients, $11.8 \%$ had no prolapse.
Vitreous prolapse led to RD in $46 \%$ of those patients and increased the number of surgeries by a factor of $18 \%$ compared to all patients. This resulted in a final mean BCVA of $1.54 \pm 0.81$ logMAR which did not differ significantly (see Table 2).

\section{Outcome}

Fig. 3 illustrates the correlation of initial to final BCVA. As can be seen, most patients improved with treatment, but 15 patients worsened (above the interrupted line). Initial mean BCVA improved from $2.16 \pm 0.86$ to $1.5 \pm 1.1$ ( $t$-test, $p<0.000$ ). Patients with pseudophakia at presentation had a significantly worse final visual outcome ( $t$-test, $p=0.03$ ), although their initial BCVA did not differ ( $t$-test, $p=0.16$ ) (see Table 2).

\section{Initial NLP}

Five out of sixteen (31\%) patients had initial NLP and did not improve despite treatment, whereas 11 improved $(69 \%)$ to counting fingers (CF) or hand movement (HM) (logMAR 2-2.1). One case did exceedingly well with an improvement of $-2.48 \log$ MAR. The mean number of surgeries was $3.0 \pm 2.1$. RD occurred in $69 \%$, 


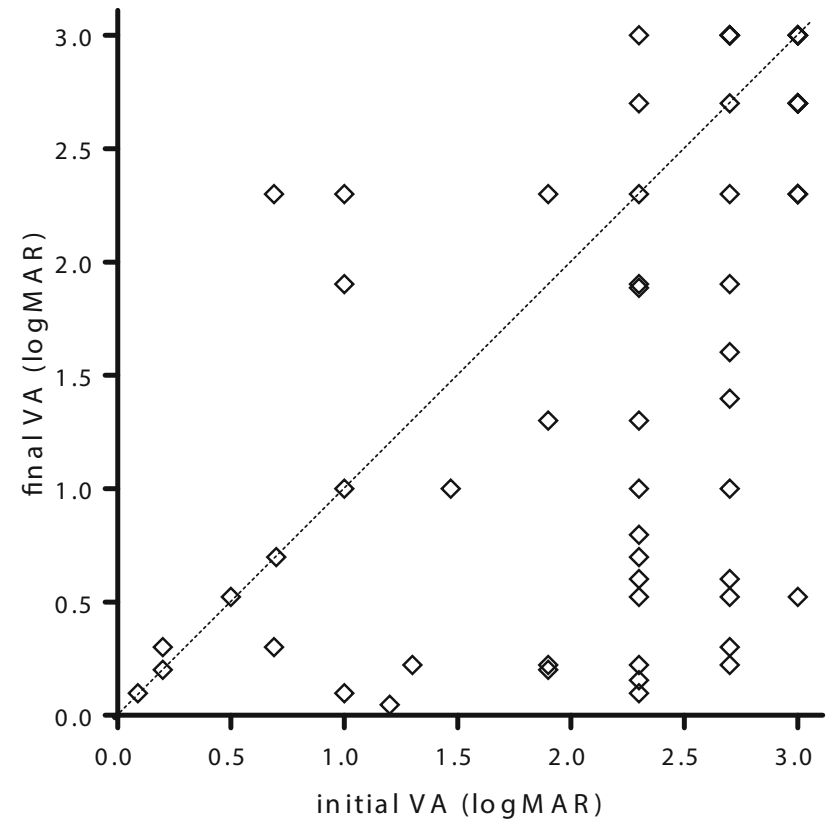

Fig. 3 Relationship between initial visual acuity to final visual acuity in logMAR. Dots below line show improvement, plotted dots above line show visual impairment

phthisis in $25 \%$ and enucleation in $19 \%$. Three of four enucleations had initial NLP.

\section{Final NLP}

All 10 patients with final NLP had initial BCVA of HM or worse. Rupture was the cause in nine of 10 cases, and one case had an intraocular foreign body which resulted in endophthalmitis.

There was a correlation between OTS and final BCVA (Spearman, $-0.86, p<0.000$ ). Of 43 patients with an OTS score of 1 , only nine patients (22\%) had a final BCVA of NLP.

\section{Therapy}

All patients received primary surgical repair and foreign body removal where needed. The mean number of surgeries was 2.85 per patient. In all, $70 \%$ of patients needed further surgical therapy other than primary surgical repair. Visual acuity reached a plateau after four surgeries (Fig. 4).

Vitrectomy was performed in 55\% of cases and silicone oil endotamponade due to $\mathrm{RD}$ was applied in $46 \%$. Those patients receiving silicone oil endotamponade showed significant improvement in BCVA ( $t$ test, $p<0.000$ ). Four patients needed enucleation.

Patients remained aphakic in $36 \%$, pseudophakic in $43 \%$ and phakic in $21 \%$ after treatment. There was a significant correlation between OTS score 1 and increased numbers of surgeries (Spearman, $-0,370$, $p=0.000$ ) (see Table 3).

\section{Endophthalmitis}

A total of four cases (4\%) with endophthalmitis were reported. All patients were treated with vitrectomy and intraocular antibiotics. Two patients resulted in NLP and one patient needed enucleation due to severe inflammation not amenable to treatment.

Sympathetic ophthalmia did not occur in the present study.

\section{Discussion}

This study aims to provide an overview of surgically treated OGI at the RWTH Aachen University Hospital
Fig. 4 Total number of surgeries performed per patient (bar) related to final mean best corrected visual acuity $( \pm 95 \%$ confidence interval)

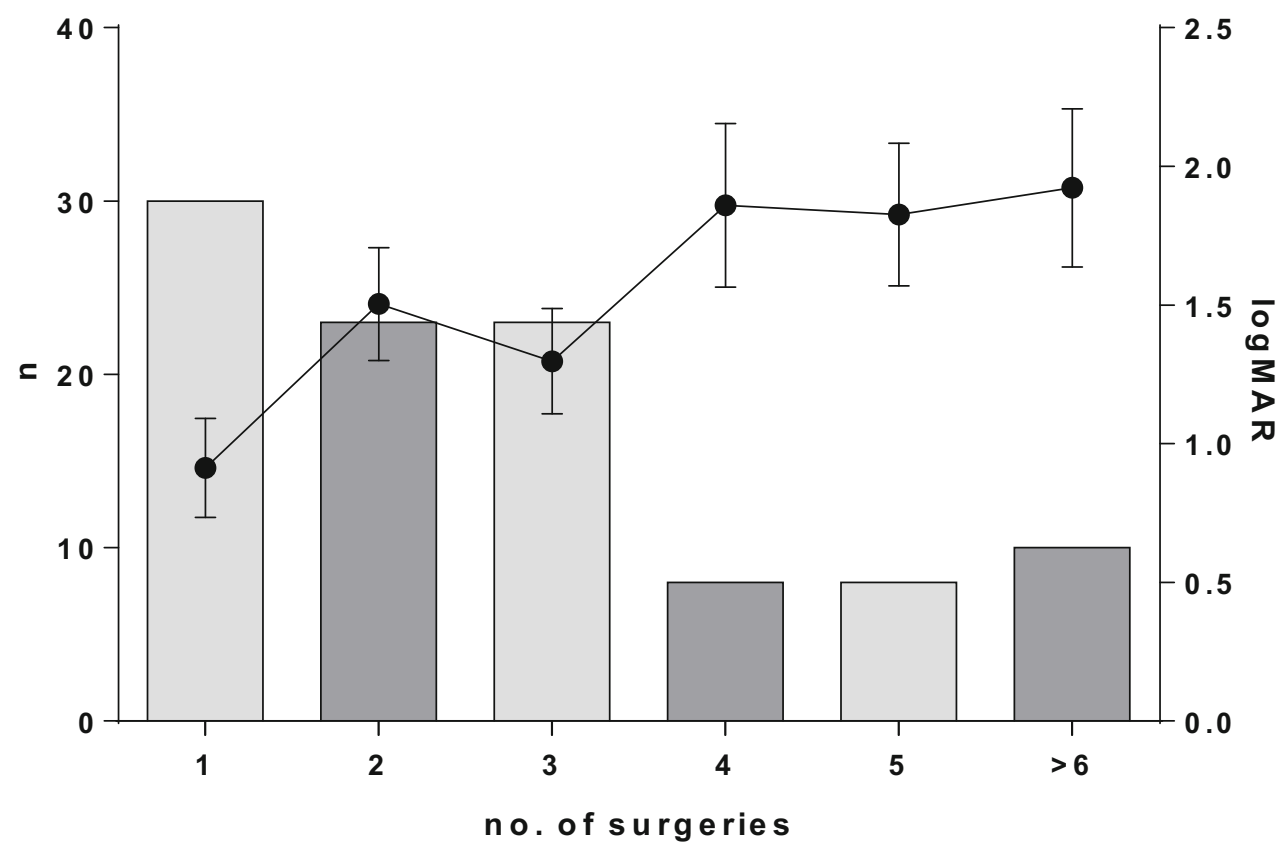


and assess the current medical care there compared to the literature.

\section{Epidemiology}

The current study identified two age peaks for men: one between 20-40 years, which is usually working age and accounts predominantly for work and spare time injuries, and a second peak between $60-80$ years. Women were affected almost exclusively above the age of 60 and mostly by syncopal episodes. Toride et al. described a similar age and gender distribution for Japan, a country with a comparable demographic and economic setting to Germany [20].

In contrast to the present results, previous papers as well as the literature from developing countries detected only a single peak for patients (10-50 years) and a higher male-to-female ratio [8-10, 13, 21, 22]. For example, Kuhn et al. analyzed the United States Eye Injury database (USEIR) and discovered that $81 \%$ of all patients were male and that both genders were single-peaked (m: 20-60 years, f: 70-80 years). This might be because the USEIR includes data of military personnel, which are obviously younger in age. In an older study in Germany, Schrader also found $84 \%$ male patients (male:female $=5.9: 1$ ) and only $9 \%$ of OGI in elderly patients, which might reflect worse work safety standards 20 years ago on the one hand [11]. On the other, demographic change has also affected the incidence of OGI in elderly patients in Germany $[23,24]$. To the best of the authors' knowledge this is the first study to clarify that male predominance has decreased in recent decades (male:female $=1.8: 1$ ). Based on the data presented here, a shifting of the first peak towards a higher second peak for both genders can be expected. Thus, one can expect to see increasing numbers of older patients with less male predominance.

The authors' annual incidence rate for hospitalized OGI (per 100,000/year) of 0.8 was significantly lower compared to 3.7 in the US [25], 3.1 in Israel [26], 6.0 in Sweden [10] and 12.6 in Singapore [13]. Patients' economic status and educational level were not evaluated. Both factors might impact the low incidence rate found in the current study.

Follow-up times showed great variance as most patients were referred to the authors' tertiary center only for surgical treatment, and data supplied by ophthalmologists were incomplete in several patients. Reasons for loss of follow-up were death, relocation or change of treating ophthalmologist.

\section{Mechanism of injury}

In the present study, penetration by metal items had the best final visual outcome $(t$-test, $p<0.000)$, which occurred mostly in men $(87.5 \%)$. In previous studies, metal objects were the main cause of injury in $32.4-72.7 \%[27,28]$. Although metal items have been identified as the causative factor for posterior OGI in young men [16], former studies have also reported that penetrating injuries resulted in better visual results [27]. These findings suggest that visual outcome depends on the mechanism of injury as well as the material of IOFB. One possible reason might be that metal splinters tend to be sharp and perforate the cornea or sclera with less trauma. Depending on the velocity of the IOFB, the penetration depth results in varying damage. Although size of IOFB was not assessed in this study, previous studies have shown a strong correlation to final vision [27, 29].

Women were frequently injured after syncopal episodes, which occurred exclusively at home or during leisure time activities. An increase in domestic OGI was also noted by Schrader in 2004. Domestic injury rates were found to be as high as $71 \%[22,30]$.

Work-related OGI occurred in $8.8 \%$ of cases, which is lower compared to other studies $(34-49 \%)[8,10]$. The incidence of work-related injuries might depend on working safety standards and socioeconomic factors not evaluated here. Gender imbalance in work-related injuries was striking in the current study. The authors did not find a single female patient with a workrelated injury. This imbalance was also previously found by others $[8,20]$.

The main mechanism of injury resulting in enucleation was rupture (75\%). This was also shown by Savar and several other authors [11, 15, 27, 31].

\section{Risk factors}

The actual existence of risk factors for poor visual outcome in OGI patients has been questioned by Page et al. [12]. While many have acknowledged the existence of risk factors for poor visual outcome, others have rejected this.

In their study, the authors evaluated the following risk factors: location of injury, vitreous prolapse, pseudophakia at presentation and initial BCVA including NLP patients.

They found that radial scleral injury with or without eye muscle involvement had a significant impact on final visual outcome, which is in line with the previous literature $[14,15,27]$.

Furthermore, patients with or without vitreous prolapse (25\% vs $75 \%$ ) did not differ in visual outcome, although the former needed more surgical procedures, including vitrectomy.

The role of pseudophakia at presentation has been discussed with contradictory results [27, 32]. While cataract surgery has evolved in recent decades, its leading role in eye ruptures has decreased due to the small self-sealing incisions used in modern cataract surgery from $40 \%$ of all OGI in 1985 [11] to $10 \%$ in the present study.

In line with the previous literature, the data presented here outline pseudophakia as a risk factor for poor visual outcome. However, as the percent- 
age of pseudophakia and the number of syncopal episodes and multimorbidity increase with age, this result might be biased.

Many previous studies have shown a correlation between initial BCVA to final BCVA [7, 14, 25, 26, 28, 33]. However, the authors found a group of interest that had visual impairment after treatment $(n=14)$. In general, the impairment was statistically non-significant ( $t$-test, $p=0.09$ ). Nevertheless, they want to point out the highly individual course which may result in a worse visual outcome. Of those 14 patients, four had endophthalmitis, three had only minimal visual impairment, which may be due to error in measurement, two had phthisis and two had retinal detachment. Three patients received only primary reconstruction due to age ( $>88$ years) and multimorbidity.

\section{Ocular Trauma Score and no light perception}

The OTS was introduced as an alternative to predict the visual outcome of OGI patients. The authors showed a significant correlation between OTS and visual outcome. However, effective prediction of the outcome remains uncertain. Kuhn et al. stated that OTS 1 has a $75 \%$ probability to have NLP as final BCVA [6]. In the authors' dataset, only $22 \%$ of OTS 1 had NLP as final outcome. In addition, their data showed an improvement for $69 \%$ of all NLP patients up to a BCVA of 0.73 logMAR.

Therefore, they conclude that conventional risk factors and OTS are insufficient to guide whether or not to proceed with further therapy. They propose deciding on a case-by-case basis and performing therapy if socioeconomic circumstances permit.

In line with the authors' results, Soni et al. found that NLP is a risk factor for poor visual outcome [34]. NLP is often associated with severe ocular tissue destruction, including the retina or optic nerve. The current patient cohort did surprisingly well with $69 \%$ improving up to CF or HM. Han et al. reported that $11.1 \%$ reached a final BCVA of light perception or better [35].

\section{Therapy}

Fig. 4 shows that after three surgeries, patients have no further improvement and reach a plateau vision of about 2 logMAR, which equals hand motion. Gursoy et al. found that number of surgeries did not have a significant effect on final BCVA [36]. Therefore, surgical procedures should be considered especially with regard to patient age, condition and risk of general anesthesia.

A prospective randomized study would be preferable, but might fail due to low numbers or inhomogeneous patient characteristics.

\section{Conclusion}

OGI is common in young working males and female seniors. The authors expect an increase in OGI for seniors in the future.

It is still difficult to predict the outcome, even if risk factors and OTS can be used to gain a general idea. The treatment of OGI remains a challenge that needs to be assessed individually.

Funding Open Access funding enabled and organized by Projekt DEAL.

\section{Compliance with ethical guidelines}

Conflict of interest Y. Djalali-Talab, B. Mazinani, and Y. Djalali-Talab declare that they have no competing interests.

Ethical standards For this article no studies with human participants or animals were performed by any of the authors. All studies mentioned were in accordance with the ethical standards indicated in each case. For this retrospective study formal consent for participation/publication is not required. This was approved by the local ethics committee (CTC-A-20541).

Open Access This article is licensed under a Creative Commons Attribution 4.0 International License, which permits use, sharing, adaptation, distribution and reproduction in any medium or format, as long as you give appropriate credit to the original author(s) and the source, provide a link to the Creative Commons licence, and indicate if changes were made. The images or other third party material in this article are included in the article's Creative Commons licence, unless indicated otherwise in a credit line to the material. If material is not included in the article's Creative Commons licence and your intended use is not permitted by statutory regulation or exceeds the permitted use, you will need to obtain permission directly from the copyright holder. To view a copy of this licence, visit http://creativecommons.org/licenses/by/4.0/.

\section{References}

1. Balta O, Acar U, Akbas Kocaoglu F, Ornek F. Review of 306 evisceration surgeries performed between 2005 and 2013. TurkJ Med Sci. 2016;46(2):463-7.

2. de Gottrau P, Holbach LM, Naumann GO. Clinicopathological review of 1146 enucleations (1980-90). Br J Ophthalmol. 1994;78(4):260-5.

3. Walter P, Rossler G, Mazinani B. Trauma with involvement of the posterior segment of the eye-part 1. Klin Monatsbl Augenheilkd. 2013;230(5):539-48. quiz 49-50.

4. Viestenz A, Schrader W, Kuchle M, Walter S, Behrens-BaumannW.Management of aruptured globe. Ophthalmologe. 2008;105(12):1163-74. quiz75.

5. Kuhn F, Morris R, Witherspoon CD, Heimann K, Jeffers JB, Treister G. A standardized classification of ocular trauma. Ophthalmology. 1996;103(2):240-3.

6. Kuhn F, Maisiak R, Mann L, Mester V, Morris R, Witherspoon CD. The ocular trauma score (OTS). OphthalmolClin North Am. 2002;15(2):163-5.

7. Yu Wai Man C, Steel D. Visual outcome after open globe injury: a comparison of two prognostic models-the ocular 
trauma score and the classification and regression tree. Eye (Lond). 2010;24(1):84-9.

8. Chang CH, Chen CL, Ho CK, Lai YH, Hu RC, Yen YL. Hospitalized eye injury in a large industrial city of South-Eastern Asia. Graefes Arch ClinExp Ophthalmol. 2008;246(2):223-8.

9. Wu M, Ye J. Hospitalized eye injury in a Chinese urban population: a 7-year retrospective analysis. Int J Ophthalmol. 2010;3(2):179-81.

10. SahraravandA, HaavistoAK, Holopainen JM, Leivo T. Ocular traumas in working age adults in Finland-Helsinki ocular trauma study. Acta Ophthalmol. 2017;95(3):288-94.

11. Viestenz A, Kuchle M. Retrospective analysis of 417 cases of contusion and rupture of the globe with frequent avoidable causes of trauma: the Erlangen ocular contusionregistry (EOCR) 1985-1995. Klin Monatsbl Augenheilkd. $2001 ; 218(10): 662-9$.

12. Page RD, Gupta SK, Jenkins TL, KarciogluZA. Riskfactors for poor outcomes in patients with open-globe injuries. Clin Ophthalmol. 2016;10:1461-6.

13. Kuhn F, Morris R, Witherspoon CD, Mann L. Epidemiology of blinding trauma in the United States eye injury registry. Ophthalmic Epidemiol. 2006;13(3):209-16.

14. Feng K, Hu Y, Wang C, Shen L, Pang X, Jiang Y, et al. Risk factors, anatomical, and visual outcomes of injured eyes with proliferative vitreoretinopathy: eye injury vitrectomy study. Retina. 2013;33(8):1512-8.

15. Feng K, Hu YT, Ma Z. Prognostic indicators for no light perception after open-globe injury: eye injury vitrectomy study. Am J Ophthalmol. 2011;152(4):654-662.e2.

16. Knyazer B, Levy J, Rosen S, Belfair N, Klemperer I, Lifshitz T. Prognosticfactors in posterior open globe injuries (zone-III injuries). Clin Exp Ophthalmol. 2008;36(9):836-41.

17. Lange C, Feltgen N, Junker B, Schulze-Bonsel K, Bach M. Resolving the clinical acuity categories "hand motion" and "counting fingers" using the Freiburg visual acuity test (FrACT). Graefes Arch Clin Exp Ophthalmol. 2009;247(1):137-42.

18. Bach M.Visual acuity chart. 2017. https://michaelbach.de/ sci/acuity.html. Accessed 9 May 2020.

19. UK EQUATOR Centre. STROBE guidelines. 2019. https:// www.equator-network.org/reporting-guidelines/strobe/. Accessed 6 May 2020

20. TorideA, ToshidaH, Matsui A, MatsuzakiY,HondaR, OhtaT, et al. Visual outcome after emergency surgery for open globe eyeinjuryin Japan. Clin Ophthalmol. 2016;10:1731-6.

21. Muller F. Relationship of age to eye injuries. Bibl Ophthalmol. 1968;19(73):157-74.

22. SchraderWF.Epidemiology of open globe eye injuries: analysis of 1026 cases in 18 years. Klin Monatsbl Augenheilkd. 2004;221(8):629-35.
23. Leivo T, Haavisto AK, Sahraravand A. Sports-related eye injuries: the current picture. Acta Ophthalmol. 2015;93(3):224-31.

24. Lehto KS, Sulander PO, Tervo TM. Do motor vehicle airbags increase risk of ocular injuries in adults? Ophthalmology. 2003;110(6):1082-8.

25. Smith AR, O'Hagan SB, Gole GA. Epidemiology of open- and closed-globe trauma presenting to Cairns Base Hospital, Queensland. Clin Exp Ophthalmol. 2006;34(3):252-9.

26. Knyazer B, Bilenko N, Levy J, Lifshitz T, Belfair N, Klemperer I, et al. Open globe eye injury characteristics and prognostic factors in southern Israel: a retrospective epidemiologic review of 10 years experience. Isr Med Assoc J. 2013;15(3):158-62.

27. Fujikawa A, Mohamed YH, Kinoshita H, Matsumoto M, Uematsu M, Tsuiki E, et al. Visual outcomes and prognostic factors in open-globe injuries. BMC Ophthalmol. 2018;18(1):138.

28. Soylu M, Sizmaz S, Cayli S. Eye injury (ocular trauma) in southern Turkey: epidemiology, ocular survival, and visual outcome. Int Ophthalmol. 2010;30(2):143-8.

29. Liu Y, Wang S, Li Y, Gong Q, Su G, Zhao J. Intraocular foreign bodies: clinical characteristics and prognostic factors influencing visual outcome and globe survival in 373 eyes. JOphthalmol. 2019;2019:5208092.

30. Falcao M, Camisa E, Falcao-Reis F. Characteristics of openglobe injuries in northwestern Portugal. Ophthalmologica. 2010;224(6):389-94.

31. Savar A, Andreoli MT, Kloek CE, Andreoli CM. Enucleation for open globe injury. Am J Ophthalmol. 2009;147(4):595-600.e1.

32. Kavoussi SC, Slade MD, Meskin SW, Adelman RA. Characteristics and outcomes of fall-related open-globe injuries in pseudophakic patients. Clin Ophthalmol. 2015;9:403-8.

33. Rouberol F, Denis P, Romanet JP, Chiquet C. Comparative study of 50 early- or late-onset retinal detachments after open or closed globe injury. Retina. 2011;31(6):1143-9.

34. Soni NG, Bauza AM, Son JH, Langer PD, Zarbin MA, Bhagat N. Open globe ocular trauma: functional outcome of eyes with no light perception at initial presentation. Retina. 2013;33(2):380-6.

35. Han SB, Yu HG. Visual outcome after open globe injury and its predictive factors in Korea. J Trauma. 2010;69(5):E66-72.

36. Gursoy H, Bilgec MD, Sahin A, ColakE. A possible regression equationfor predictingvisual outcomes after surgicalrepair of open globe injuries. JOphthalmol. 2017;2017:1320457.

Publisher's Note Springer Nature remains neutral with regard to jurisdictional claims in published maps and institutional affiliations. 